University of Nebraska - Lincoln

DigitalCommons@University of Nebraska - Lincoln

2013

\title{
On the halophytic nature of mangroves
}

Ken W. Krauss

U.S. Geological Survey, kkrauss@usgs.gov

Marilyn C. Ball

Australian National University, Marilyn.ball@anu.edu.au

Follow this and additional works at: https://digitalcommons.unl.edu/usgsstaffpub

Krauss, Ken W. and Ball, Marilyn C., "On the halophytic nature of mangroves" (2013). USGS Staff -Published Research. 712.

https://digitalcommons.unl.edu/usgsstaffpub/712

This Article is brought to you for free and open access by the US Geological Survey at DigitalCommons@University of Nebraska - Lincoln. It has been accepted for inclusion in USGS Staff -- Published Research by an authorized administrator of DigitalCommons@University of Nebraska - Lincoln. 


\title{
On the halophytic nature of mangroves
}

\author{
Ken W. Krauss $\cdot$ Marilyn C. Ball
}

Received: 30 July 2012/Accepted: 10 August 2012/Published online: 5 September 2012

(C) Springer-Verlag (outside the USA) 2012

\begin{abstract}
Scientists have discussed the halophytic nature of intertidal plants for decades, and have generally suggested that inherent differentiation of an obligate halophyte from a facultative halophyte relates strongly to whether the plant can survive in fresh water, and not much else. In this minireview, we provide additional insight to support the pervasive notion that mangroves as a group are truly facultative halophytes, and thus add discourse to the alternate view that mangroves have an obligate salinity requirement. Indeed, growth and physiological optima are realized at moderate salinity concentrations in mangroves, but we maintain the notion that current evidence suggests that survival is not dependent upon a physiological requirement for salt.
\end{abstract}

Keywords Facultative halophyte $\cdot$ Mangrove $\cdot$ Obligate halophyte $\cdot$ Salinity tolerance $\cdot$ Vivipary

\section{Introduction}

For over 70 years, scientists have discussed ways to categorize coastal vegetation by salinity tolerance in order to understand the differential distribution of species along

Communicated by R. Guy.

K. W. Krauss $(\bowtie)$

US Geological Survey, National Wetlands Research Center,

700 Cajundome Blvd, Lafayette, LA 70506, USA

e-mail: kkrauss@usgs.gov

\section{C. Ball}

Division of Plant Sciences, Research School of Biology,

College of Medicine, Biology and Environment,

Australian National University, The RN Robertson Bldg. (\#46),

Biology Place, Canberra, ACT 0200, Australia

e-mail: Marilyn.ball@anu.edu.au natural salinity gradients (Uphof 1941; Chapman 1960, 1976). Understanding the role that salinity plays in the establishment, productivity, and mortality of coastal plants is no easy task, but forms the basis of many ecological modeling efforts targeting coastal change. Mangrove communities represent one such group of marine halophytes for which understanding individual species advancement through different life history stages is often framed within the context of salinity tolerance (Tomlinson 1986; Ball 1988; Parida and Jha 2010). In fact, no other environmental factor is more pervasive in the mangrove literature than salinity; mangroves tolerate it, are influenced by it, and have high rates of productivity in spite of it (Alongi 2009). Inherent to this understanding is a discussion of the halophytic nature of mangroves.

In a recent review, Wang et al. (2011) offered a number of observations in support of the notion that mangroves were indeed obligate halophytes, and thus "... can grow in freshwater for a limited time but not throughout their entire life cycles" (p. 960). This article represents a commendable review of the literature, but concludes quite opposite to what the evidence suggests, in that from a physiological perspective mangroves are truly facultative halophytes. Herein, we expand on this review and emphasize for mangroves what Michael Barbour reported more generally for halophytes in 1970:

The conflicting results reported in the literature, and the limitations of the methods employed, do not lead one to make sweeping conclusions about salt tolerance limits of halophytic genera or species. However, the weight of evidence to date fails to reveal conclusively the existence of any obligate angiosperm halophyte and only a relatively few cases of facultative halophytes (Barbour 1970, p. 117). 
Mangroves of the genera Bruguiera, Rhizophora, Kandelia, and Ceriops were among the "relatively few cases" mentioned. While we suspect that a discussion of whether mangroves need to be categorized in any way beyond "halophyte" will remain an ongoing debate (cf., Flowers et al. 1977), we would like to clarify the primary difference between an obligate and facultative halophyte and contribute to this discussion.

\section{Facultative versus obligate halophytes}

Halophytes have been defined "as plants which survive to complete their life cycle at high salinities" (Flowers et al. 1977, pp. 95-96). Many halophytes depend on seasonal reductions in salinity to improve germination or enhance growth even though salinity may be high during the remainder of the year. Very little data support a physiological requirement for salt among surveyed halophytic taxa (Flowers et al. 1977); halophytes simply tolerate salinity. This distinction has also historically been applied to mangroves (McMillan 1974; Tomlinson 1986; Ball 1988). Categorizing halophytic taxa along the basis of a physiological salinity requirement should not be confounded by defining salinity optima.

To explain, we categorize coastal plants as non-halophytes, facultative halophytes, and obligate halophytes graphically by relating productivity and/or physiological proficiency to salinity (Fig. 1). Non-halophytes, which include many taxa, survive optimally in fresh water and mortality is imminent at slightly higher salinity concentrations. These species would not be considered halophytes because growth or physiological proficiency is not improved with salinity. Facultative halophytes are also able to grow in fresh water, but differ from non-halophytes in responding to increases in salinity with promoted growth, up to an optimum level, above which growth would decrease. Finally, obligate halophytes have optimal growth under ranges of salinity similar or greater to those of facultative halophytes but differ in their inability to survive under fresh water conditions (Fig. 1). Therefore, discussions of optimum salinity concentrations for growth in mangroves are not important to the distinction between facultative and obligate halophytes. Rather, the distinction is related to the need for salinity in order to survive.

For obligate halophytes to be identified separately from facultative halophytes, it is important to define what an obligate halophyte needs from dissolved salts that other plants do not. An example is the obligate halophytic bacteria, Halobacterium, which live only in the concentrated salts of solar evaporation ponds and salt lakes (Fig. 1). In this case, Halobacterium requires high $\mathrm{Na}^{+}$concentrations for physical membrane stability and amino acid uptake

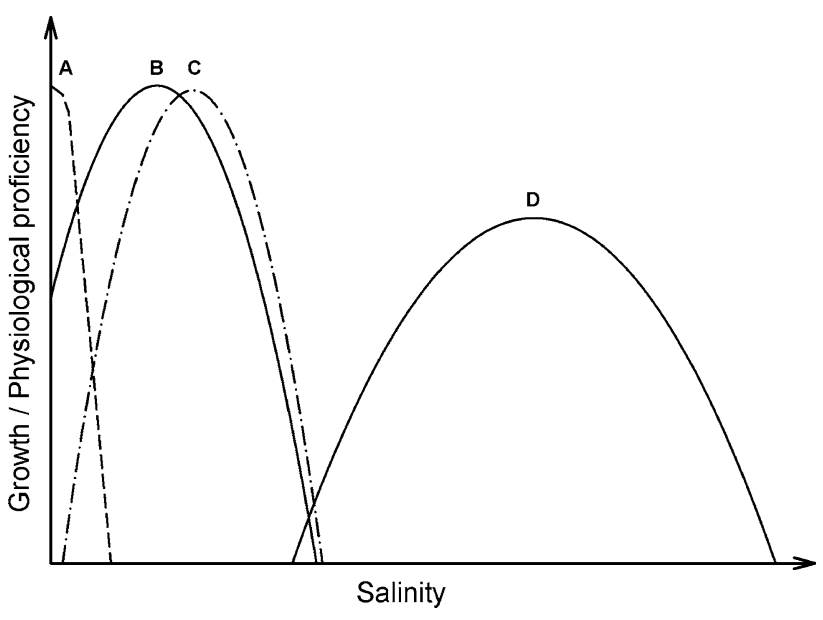

Fig. 1 Theoretical growth or physiological proficiency curves relative to increases in salinity for $A$ non-halophytes, $B$ facultative halophytes, and $C$ obligate halophytes. Also depicted is a theoretical response for an extreme halophyte ( $D$, Halobacterium spp.), also obligate in that this bacteria cannot survive unless salinities are very high. Diagram modified from descriptions in Ingram (1957), Barbour (1970), Gibbons (1974), and Greenway and Munns (1980)

with $\mathrm{Mg}^{2+}$ requirements differing by strain (Tindall et al. 1980; Cohen et al. 1983). Without salinity, these bacteria cannot live. Such stringent requirements have not been defined for mangroves, and we argue that the evidence available in the literature supports mangroves as facultative halophytes, not obligate halophytes.

\section{Perspectives from short-term studies on seedlings}

Studies on seedlings, in lieu of saplings and trees, dominate the mangrove literature (Krauss et al. 2008; Wang et al. 2011). This is certainly a limitation on developing a complete understanding of the physiological ecology of mangroves as halophytes, especially since the definition of halophyte relates to all life history stages. Multiple studies, however, do indicate adequate survival of mangroves in fresh water (Wang et al. 2011); to these we can add descriptions by Barbour (1970), McMillan (1974), Chapman (1976), and Tomlinson (1986). Importantly, scientists have observed, cultivated, and tracked survival of mangroves under fresh water conditions in the field, laboratory, and greenhouse at multiple life history stages. Consequently, as a group (i.e., defined as approximately 70 species and/or hybrids globally, Duke et al. 1998), mangroves have the ability to survive in fresh water, even though growth potential may be reduced to various degrees among species.

Experimental studies have documented reduced growth of mangrove seedlings in fresh water (Downton 1982; Clough 1984), but few studies focus on the correct metric-mortality. Higher osmotic potentials can actually 
influence cell expansion, which drives tissue growth in all plants. Appropriate studies would need to distinguish this effect experimentally from other possible positive effects associated with increased salinity in halophytes. We would like to reiterate here that reduced growth at low salinity without mortality is the very definition of a facultative, not obligate, halophyte (Fig. 1). For example, while it is clear that Avicennia seedlings in Downton (1982) and Clough (1984) may have died eventually given their apparent physiological state when final surveys were concluded at approximately 11 months, seedling mortality was not documented. Werner and Stelzer (1990) provided a true exception to this by documenting mortality of Rhizophora mangle seedlings grown in fresh water for about a year (compared to seedlings grown at $200 \mathrm{~mol} \mathrm{~m}^{-3} \mathrm{NaCl}$ ). We suggest that offering one apparent exception should not trump more numerous studies and observations. Even low levels of salinity addition or fertilization can alleviate experimentally imposed nutrient deficiency. Hence, it is unclear to what degree other factors besides salinity may have exerted influence on past survival observations (e.g., correlative effects between salinity amendment and nutrient deficiency).

\section{Vivipary}

Vivipary offers mangroves an advantage to colonizing intertidal environments (Tomlinson and Cox 2000); however, it is unclear why vivipary would be considered characteristic of an obligate halophytic nature for mangroves (sensu Wang et al. 2011). Simply stated, salinity is not required to make vivipary work, and true vivipary has also evolved in non-saline habitats (Elmqvist and Cox 1996). With that said, early studies on vivipary did make implicit linkages to salt (e.g., Joshi 1933); true vivipary appears in only a handful of angiosperms globally and most, including some sea grasses, are indeed restricted to shallow marine habitats (Elmqvist and Cox 1996).

The reproductive counterpart of viviparous propagules, seeds, provides very specific advantages to terrestrial plants; they provide stability for plant tissue in unfavorable environments, facilitate dispersal, and contain early carbohydrate reserves for germinating seedlings (Harper 1977). For shallow marine habitats, “...taxa with seed dormancy or seed dispersal mechanisms enjoy no particular advantage" (Elmqvist and Cox 1996, p. 7), which may open the possibility for the development of vivipary by creating fitness gains associated with rapid establishment. Furthermore, precocial seed germination reflects insensitivity to, or escape from, abscisic acid (ABA) influences in plants while rooting in flooded soils; ABA is an inhibitor of germination but the production of ABA can even be stimulated in some plant species as root zones become more oxygen-deficient (Taiz and Zeiger 2002).

No explanation for vivipary is related in an obvious way to a requirement for salt. Smith and Snedaker (1995) did suggest that propagule tissues are more sensitive to salinity at early developmental stages, thus possibly explaining their retention on the parent tree before abscission as a mechanism of salinity avoidance during this stage. Relative salt tolerance of dispersing propagules can even be related to the salinity concentrations during development (Smith and Snedaker 1995). While preconditioning under different salinity regimes may be advantageous to enhancing the salt tolerance of propagules, studies have also not suggested an obligate, preconditioning requirement for salinity. Several mangrove genera also reproduce with seeds (e.g., Xylocarpus, Sonneratia). Thus, reproductive strategies employing seeds and propagules alike have been widely described in facultative halophytes globally (Elmqvist and Cox 1996; Friess et al. 2012).

\section{Physiology}

All halophytes exhibit a growth or physiological optimum related to salinity (Fig. 1). Growth conditions leading up to and exceeding optimum conditions manifest as changes in a number of variables, from morphological (e.g., leaf area, specific leaf area, etc.) to physiological (e.g., leaf gas exchange, cell wall elasticity, etc.), all affecting growth and ultimately survival (Poorter et al. 2012). When salinity is suboptimal for growth, increase in growth with increase in salinity may reflect increasing availability of nutrients or higher osmotic potentials required to support photosynthesis and growth. Still, much uncertainty remains regarding a possible mechanism for growth reductions at sub- and supra-optimal salinities (Flowers and Colmer 2008). However, once seedling propagule reserves are expended, mangroves have to cope with their environment and function as full autotrophs (Ball 2002); if resources such as light or nutrients are too limiting, seedlings will not advance to the sapling stage. Undoubtedly, if mangroves are grown in fresh water in a greenhouse without nutrient additions (e.g., Yan et al. 2007), nutrient limitations will ensue once reserves are expended.

Furthermore, some data indicate that enzymes of halophytes and non-halophytes have similar sensitivities to salts and that salt tolerance is conferred through other mechanisms (e.g., exclusion of salts: Flowers et al. 1977; Ball and Anderson 1986). The discovery that isolated superoxide dismutase (SOD) in Bruguiera gymnorrhiza leaves is insensitive to fairly high levels of salinity (Takemura et al. 2000) presumably relates to structural features of the enzyme; there is no evidence that the enzyme would ever be 
exposed to such high concentrations of ions in vivo, and furthermore the stability of the enzyme during exposure to high ionic strength would have no bearing on whether $B$. gymnorrhiza requires salt to survive. The stability of enzymes could contribute to mangrove function under optimal salinities (Parida and Jha 2010) but provides no explanation for why mangroves would die in fresh water.

\section{$\mathrm{Na}^{+}$and $\mathrm{Cl}^{-}$requirements}

$\mathrm{Na}^{+}$and $\mathrm{Cl}^{-}$are involved in mangrove physiological function. Many plants, including non-halophytes, rely on these ions for osmotic balance, maintenance of guard cell turgor, and thylakoid functioning (Marschner 1995; Taiz and Zeiger 2002). Although their specific role in mangroves is in need of further study (Ball 2002), there is little evidence to date that mangroves growing naturally in fresh water settings would be starved physiologically for either ion. $\mathrm{Cl}^{-}$ions are supplied adequately by rainfall under most situations (White and Broadley 2001). Comparable uptake of $\mathrm{Na}^{+}$and $\mathrm{Cl}^{-}$under low and high salinities in experimental culture (cf., Patel and Pandey 2009) may be more suggestive of an adaptation to a low nutrient environment than to a physiological requirement for $\mathrm{Na}^{+}$and $\mathrm{Cl}^{-}$from a seawater source. Mangroves possess a number of mechanisms for coping with low nutrient environments, including efficient uptake and retention of essential nutrients (Reef et al. 2010). Many other plant species-nonhalophytes and halophytes-show rapid uptake of $\mathrm{Cl}^{-}$ when subjected to low ambient concentrations of $\mathrm{Cl}^{-}$, and growth is often reduced for these same plants in $\mathrm{Cl}^{-}$-free media (White and Broadley 2001).

\section{Fluctuations in salinity}

Mangroves occurring within the upper intertidal influences of rivers often flourish in seemingly fresh water conditions, although salinity can fluctuate to higher concentrations seasonally through pulses of seawater. Salinity fluctuations reflect a balance of riverine discharge during wet and dry periods of the year and can also shift among years. Wang et al. (2011) suggests that these fluctuations, whereby salinity is elevated seasonally, are required for persistence of mangroves. However, as noted by Wang et al. (2011), this distribution can also reflect an "ecological requirement" (sensu Saenger 2002), whereby salinity reduces competition from other tree species rather than alleviating physiological dysfunction within mangroves. Specific, on-topic studies from the field are not widely available, but neither mechanism would preclude the other mechanism. What studies have suggested, however, is that salinity pulses contributed greatly to the competitive exclusion of non-mangroves at low salinities (Ball and Pidsley 1988, 1995), and seedlings and saplings growing under controlled settings do not appear to require salinity (Krauss et al. 2008).

More attention should be devoted to simulating and documenting daily and seasonal fluctuations in salinity within greenhouse designs and field studies (sensu Wang et al. 2011). Nevertheless, the current evidence simply cannot disentangle a physiological requirement for salinity from the possibility of competitive exclusion along natural salinity gradients. This same criticism relates to specific mechanisms of salt tolerance, e.g., leaf succulence. Mechanisms of salt tolerance have been reviewed for both halophytes (Flowers et al. 1977) and non-halophytes (Greenway and Munns 1980), and all mechanisms suggested attempt to explain promoted growth and physiological functioning in plants at optimal salinity concentrations, ranging from fresh (non-halophyte) to salt (halophyte). Leaf succulence, for example, is merely a mechanism that some mangroves and many other halophytes (e.g., Batis spp.) may use to tolerate high salinity levels and would not apply differentially to defining an obligate versus facultative halophytic nature (Fig. 1).

\section{Conclusions}

Here, we suggest that there is currently no real contradiction to the view that mangroves as a group are facultative halophytes because mangroves can survive and tolerate fresh water. However, there is a continuum of salt tolerance within mangroves ranging from species that are salt sensitive to those that require higher levels of salt for optimal growth and reproduction. Among those species, growth is induced to an optimum between 5 and $75 \%$ seawater concentrations (Krauss et al. 2008). To be classified as facultative halophytes, mangroves do not need to grow well in fresh water, they just have to tolerate fresh water well enough to survive. We suggest that the broad nature of this categorization is much more indicative of the plethora of studies conducted on mangroves over the last century.

Acknowledgments We thank the US Geological Survey Climate and Land Use Change R\&D Program and the Australian Research Council (Discovery Project DP1096749) for research support. Karen L. McKee, Robert D. Guy, and Ulrich Lüttge provided reviews of previous manuscript drafts. Any use of trade, product, or firm names is for descriptive purposes only and does not imply endorsement by the US Government.

\section{References}

Alongi DM (2009) The energetics of mangrove forests. Springer, New York 
Ball MC (1988) Ecophysiology of mangroves. Trees Struct Funct 2:129-142

Ball MC (2002) Interactive effects of salinity and irradiance on growth: implications for mangrove forest structure along salinity gradients. Trees Struct Funct 16:126-139

Ball MC, Anderson JM (1986) Sensitivity of photosystem II to $\mathrm{NaCl}$ in relation to salinity tolerance: comparative studies with thylakoids of the salt tolerant mangrove, Avicennia marina and the salt sensitive pea, Pisum sativum. Aust J Plant Physiol 13:689-698

Ball MC, Pidsley SM (1988) Establishment of mangrove seedlings in relation to salinity. In: Larson HK, Michie JR, Hanley JR (eds) Proceedings of a workshop on research and management held in Darwin. Australian National University Press, Canberra, pp 123-134

Ball MC, Pidsley SM (1995) Growth response to salinity in relation to distribution of two mangrove species, Sonneratia alba and $S$. lanceolata. Funct Ecol 9:77-85

Barbour MG (1970) Is any angiosperm an obligate halophyte? Am Nat $84: 105-120$

Chapman VJ (1960) Salt marshes and deserts of the world. Interscience Publishers, New York

Chapman VJ (1976) Mangrove vegetation. J. Cramer, Vaduz

Clough BF (1984) Growth and salt balance of the mangroves Avicennia germinans (Forsk.) Vierh. and Rhizophora stylosa Griff. in relation to salinity. Aust J Plant Physiol 11:419-430

Cohen S, Oren A, Shilo M (1983) The divalent cation requirement of Dead Sea halobacteria. Arch Microbiol 136:184-190

Downton WJS (1982) Growth and osmotic relations of the mangrove Avicennia marina, as influenced by salinity. Aust J Plant Physiol 9:519-528

Duke NC, Ball MC, Ellison JC (1998) Factors influencing biodiversity and distributional gradients in mangroves. Glob Ecol Biogeogr Letts 7:27-47

Elmqvist T, Cox PA (1996) The evolution of vivipary in flowering plants. Oikos 77:3-9

Flowers TJ, Colmer TD (2008) Salinity tolerance in halophytes. New Phytol 179:945-963

Flowers TJ, Troke PF, Yeo AR (1977) The mechanism of salt tolerance in halophytes. Ann Rev Plant Physiol 28:89-121

Friess DA, Krauss KW, Horstman EM, Balke T, Bouma TJ, Galli D, Webb EL (2012) Are all intertidal wetlands naturally created equal? Bottlenecks, thresholds and knowledge gaps to mangrove and saltmarsh ecosystems. Biol Rev 87:346-366

Gibbons NE (1974) Halobacteriaceae. In: Buchanan RE, Gibbons NE (eds) Bergey's manual of determinative bacteriology. Williams \& Wilkins, Baltimore, pp 269-273

Greenway H, Munns R (1980) Mechanisms of salt tolerance in nonhalophytes. Ann Rev Plant Physiol 31:149-190

Harper JL (1977) The population biology of plants. Academic Press, London

Ingram M (1957) Microorganisms resisting high concentrations of sugars and salts. In: Williams RAO, Spicer CC (eds) Seventh symposium of the Society for General Microbiology. Cambridge University Press, Cambridge, pp 90-133

Joshi AC (1933) A suggested explanation of the prevalence of vivipary on the sea-shore. J Ecol 21:209-212

Krauss KW, Lovelock CE, McKee KL, López-Hoffman L, Ewe SML, Sousa WP (2008) Environmental drivers in mangrove establishment and early development: a review. Aquat Bot 89:105-127

Marschner H (1995) Mineral nutrition of higher plants. Academic Press, London

McMillan C (1974) Salt tolerance of mangroves and submerged aquatic plants. In: Reimold RJ, Queen WH (eds) Ecology of halophytes. Academic Press, New York, pp 379-390

Parida AK, Jha B (2010) Salt tolerance mechanisms in mangroves: a review. Trees Struct Funct 24:199-217

Patel NT, Pandey AN (2009) Salinity tolerance of Aegiceras corniculatum (L.) Blanco from Gujarat coastal of India. Anales de Biología 31:93-104

Poorter H, Niklas KJ, Reich PB, Oleksyn J, Poot P, Mommer L (2012) Biomass allocation to leaves, stems and roots: meta-analyses of interspecific variation and environmental control. New Phytol 193:30-50

Reef R, Feller IC, Lovelock CE (2010) Nutrition in mangroves. Tree Physiol 30:1148-1160

Saenger P (2002) Mangrove ecology, silviculture and conservation. Kluwer, Dordrecht

Smith SM, Snedaker SC (1995) Salinity responses in two populations of viviparous Rhizophora mangle L. seedlings. Biotropica 27:435-440

Taiz L, Zeiger E (2002) Plant physiology, 3rd edn. Sinauer Associates, Massachusetts

Takemura T, Hanagata N, Sugihara K, Baba S, Karube I, Dubinsky Z (2000) Physiological and biochemical responses to salt stress in the mangrove, Bruguiera gymnorrhiza. Aquat Bot 68:15-28

Tindall BJ, Mills AA, Grant WD (1980) An alkalophilic red halophilic bacterium with a low magnesium requirement from a Kenyan soda lake. J Gen Microbiol 116:257-260

Tomlinson PB (1986) The botany of mangroves. Cambridge University Press, Cambridge

Tomlinson PB, Cox PA (2000) Systematic and functional anatomy of seedlings in mangrove Rhizophoraceae: vivipary explained? Bot J Linn Soc 134:215-231

Uphof JC (1941) Halophytes. Bot Rev 7:1-58

Wang W, Yan Z, You S, Zhang Y, Chen L, Lin G (2011) Mangroves: obligate or facultative halophytes? A review. Trees Struct Funct 25:953-963

Werner A, Stelzer R (1990) Physiological responses of the mangrove Rhizophora mangle grown in the absence and presence of $\mathrm{NaCl}$. Plant Cell Environ 13:243-255

White PJ, Broadley MR (2001) Chloride in soils and its uptake and movement within the plant: a review. Ann Bot 88:967-988

Yan Z, Wang W, Tang D (2007) Effect of different time of salt stress on growth and some physiological processes of Avicennia marina seedlings. Mar Biol 152:581-587 